\section{地震時変動軸力の大きな高層建 \\ 物を支持するパイルド・ラフト 基礎}

\author{
鈴木直子— $* 1$ \\ 茶谷文雄——3 \\ 田中耕太郎 - * 5 \\ キーワード : \\ 高層建物, パイルド・ラフト基礎，沈下，水平抵抗 \\ 関 崇夫- $* 2$
佐俣紀一郎 $-* 4$ \\ 佐俣紀一郎 一*4
}

Keywords :

High building, Piled raft foundation, Settlement, Lateral resistance

\title{
PILED RAFT FOUNDATION SUPPORTING HIGH BUILDING UNDER OVER-TURNING MOMENT DUE TO EARTHQUAKE
}

\author{
Naoko SUZUKI — $* 1$ \\ Fumio CHATANI $-* 3$ \\ Kotaro TANAKA $-* 5$
}

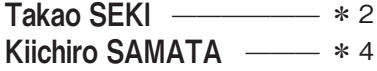

In this paper, the piled raft foundation is supported with thin cement treated soil layer below the raft and various length of friction piles. The part of this raft has a possibility of rising to the surface by over-turning moment of the tall building during a big earthquake. The authors present the outline of designing the foundation, the comparative studies on estimated settlements and measured results, and the analysis results of the lateral resistance of the piled raft which considered the rising zone of the raft from the surface.
1.はじめに

超高層建物を支持寸るパイルド・ラフト基礎に関しては既に多く の事例報告がなされている ${ }^{1)}$ こここでは，下記のような特徵がある 高層建物を支持するパイルド・ラフト基礎の計画，沈下予測解析と 実測結果との比較, 浮上がりを考慮した基礎の耐震設計の考え方等 について報告する。

長期荷重時において，建物の外周部の荷重が内部よりかなり大き い。また，高層建物であるにもかかわらず，地下室がなく上部構造 の保有耐力時には浮上がりが生じる。このような長期および大地震 時の荷重条件を考慮し，パイルド・ラフト基礎の杭長は一定ではな く, 建物の隅角, 辺, 内部で異なる長さの杭を採用している。

\section{2. 建物・地盤概要と基礎構造の計画}

建物は, 地上 24 階, 塔屋 2 階の鉄筋コンクリート造の高層集合住 宅である。建物の平面は概略 $22 \times 22 \mathrm{~m}$ の正方形で，軒高は $76 \mathrm{~m} ，$ 塔 状比は 3.4 とやや大きい（図 1，2）。各柱位置に作用する長期荷重 をその支配面積で除した荷重度は，建物の中央部，辺部，隅角部の 順に大きく，柱位置によって大きく異なっている（図 3 a )。

建設地は福島盆地の中央部にあり，阿武隈川の支流によって形成 された段丘上にある。地表面から深さ $5 \mathrm{~m}$ までは砂質土系の埋戻し土 であり，それ以深は砂礫，粘性土，砂質土の互層からなる洪積層が 厚く堆積するものの， $N$ 值が 50 以上の明確な支持層は深さ約 $70 \mathrm{~m}$ 以深にある（図 4)。

基礎梁せいを $3 \mathrm{~m}$ とする二重スラブ（以下，ラフトと呼称）の採用
と,ラフト下の層厚約 $2 \mathrm{~m}$ の埋戻し土部分を簡易な流動化処理土工法 で地盤改良するとの前提で，べた基礎の可能性を検討した。

建物の平均接地圧は $350 \mathrm{kN} / \mathrm{m}^{2}$ であるが，建物外周部が内部より大 きな柱軸力分布と, ラフトの剛性による荷重再配分効果を考慮した 接地圧は $180 \sim 460 \mathrm{kN} / \mathrm{m}^{2}$ となる（図 $3 \mathrm{~b}$ )。

一方, 深さ $15 \mathrm{~m}$ 付近の粘性土層の一軸圧縮強さは $210 \mathrm{kN} / \mathrm{m}^{2}$ であ

り，層状地盤としての長期許容支持力度は粘性土層で決まり，476 $\mathrm{kN} / \mathrm{m}^{2}$ と最大接地圧を上回る。

また，べた基礎としたときの最大即時沈下量は約 $27 \mathrm{~mm}$ ，ラフト下 の各粘性土層は建物建設に伴う荷重増に対して,十分過圧密であり, 有害な圧密沈下が生じる可能性はない。

以上，地盤改良の採用によって長期荷重に対してべた基礎による 支持が可能と判断されたが，下記の理由により杭を併用したパイル ド・ラフト基礎を採用する方針とした。

(1)建物の重要性を考慮し，地盤改良だけに頼らず，杭の併用によっ て支持力に関する安全性を高めるとともに沈下量を低減する。

(2)杭の併用によって大地震時の軸力変動に伴う浮上り量と沈下量の 低減を図る。杭は直径 $1.5 \mathrm{~m}$ の場所打ちコンクリート杭による摩擦 杭とし, 杭長は, 隅角部, 辺部, 中央部の各杭の地震時負担軸力 の大きさを考慮し, それぞれ $35,30,25 \mathrm{~m}$ と寸る。また, 大きな引 抜き力・押込み力と水平力が作用する隅角部の杭は上部 $5 \mathrm{~m}$ を鋼管 巻きとする。

また，地盤定数の評価を含むFEMによるパイルド・ラフト基礎の 解析精度がラフトと杭の荷重分担に与える影響を考慮し, 各荷重

\footnotetext{
*1 (侏)大林組技術研究所地盤技術研究部 副主査

（テ204-8558 東京都清瀬市下清戸4-640）

*2 (侏大林組技術研究所地盤技術研究部 主任研究員 ·博士 (工学)

*3 株大林組技術研究所地盤技術研究部 博士 (工学)

*4 (侏)大林組名古屋支店建築設計部 副主査

*5 侏大林組本店設計品質管理部 部長
}

\footnotetext{
${ }^{* 1}$ Deputy Manager, Geotechnical Engineering Department, Technical Research Institute, Obayashi Corporation

* 2 Senior Research Engineer, Geotechnical Engineering Department, Technical Research Institute, Obayashi Corporation, Dr. Eng.

*3 Geotechnical Engineering Department, Technical Research Institute, Obayashi Corporation, Dr. Eng.

*4 Deputy Manager, Nagoya Branch, Architectural \& Engineering Department, Obayashi Corporation

*5 General Manager, Main Office, Quality Control Department, Obayashi Corporation
} 
表 1 荷重条件と基礎各部の設計方針

\begin{tabular}{|c|c|c|c|c|c|}
\hline 荷重条件 & ラフト下の地盤の支持力 & ラフトの滑動抵抗 & \begin{tabular}{|c|}
$\begin{array}{c}\text { 杭の支持力および引抜 } \\
\text { き抵抗力 }\end{array}$ \\
\end{tabular} & & 部材の断面設計 \\
\hline \multirow{2}{*}{ 長期荷重時 } & \multirow{2}{*}{$\begin{array}{l}\text { 杭の存在を無視したべた基 } \\
\text { 礎としての最大接地圧 } \\
\text { <長期許容支持力度 }\end{array}$} & & \multirow{2}{*}{$\begin{array}{l}\text { パイルド・ラフト基礎とし } \\
\text { ての沈下の検討で代替 } \\
\text { する }\end{array}$} & ラフト・基礎梁 & $\begin{array}{l}\text { 杭の存在を無視したべた基礎 } \\
\text { として長期許容応力度で設計 }\end{array}$ \\
\hline & & & & 杭 & $\begin{array}{l}\text { 負担軸力*に対して } \\
\text { 長期許容応力度で設計 }\end{array}$ \\
\hline 設計用地震荷重時 & $\begin{array}{c}\text { ラフトが負担する斜め荷重* } \\
\text { <短期許容支持力度 }\end{array}$ & $\begin{array}{l}\text { •基礎スラブに浮上がりが生じない } \\
\text { •ラフトの負担水平力 } \\
\text { （ } \\
\text { <ラフトの最大摩擦抵抗 }\end{array}$ & $\begin{array}{l}\text { 杭の負担荷重 } \\
<\text { 短期許容支持力 }\end{array}$ & $\begin{array}{c}\text { ラフト・基礎梁 } \\
\text { 杭 }\end{array}$ & $\begin{array}{l}\text { 各部の負担荷重*に対して } \\
\text { 短期許容度で設計 }\end{array}$ \\
\hline
\end{tabular}

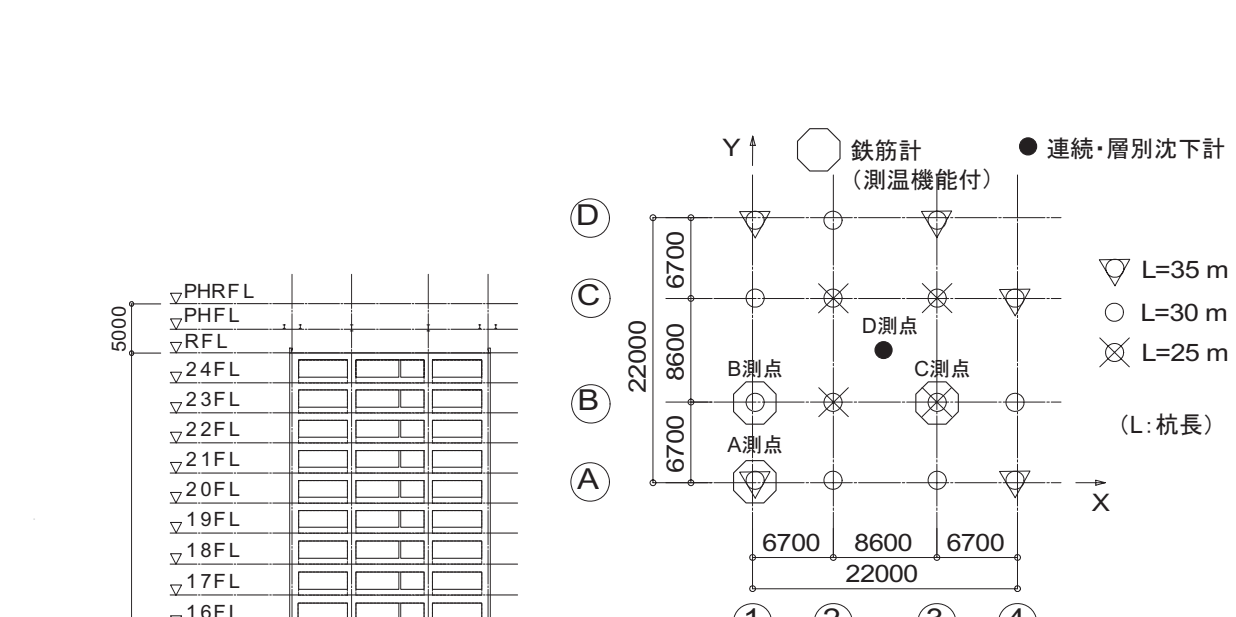

(1) (2) (4)

図 2 建物の平面形状、杭配置、計器配置

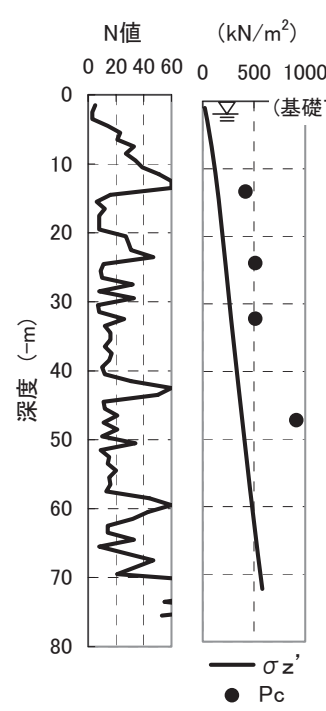

条件に対してラフト下の地盤の支持力, 各部材断面の強度等は, 各 部の解析上の負担荷重に対して $20 \%$ の余裕度を確保する（表 1)。

\section{3. 長期荷重に対する基礎の沈下予測解析と実測結果との比較}

\section{（1）沈下予測解析}

長期荷重に対する基礎の即時沈下と圧密沈下の検討は，汎用 FEM 解析ソフトABAQUS を用いて, 三次元非線形FEMによって行った。解 析モデルを図 5 に示した。地盤は非線形ソリッド要素で, 初期変形
(D) $390-280-520$

(c) $370-260-280-470$

(B) $-370+260-270+390$

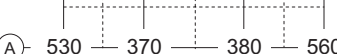
(1) 2
(3) (4)

(a)ラフト剛性無視（軸力 $\div$ 柱の負担面積）

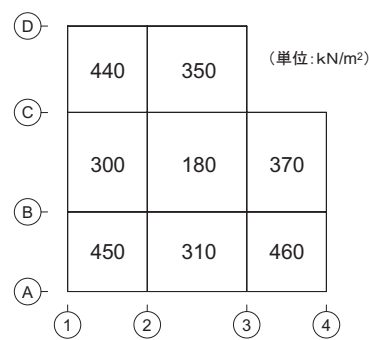

(b)ラフト剛性考慮

図 3 ラフトの接地圧

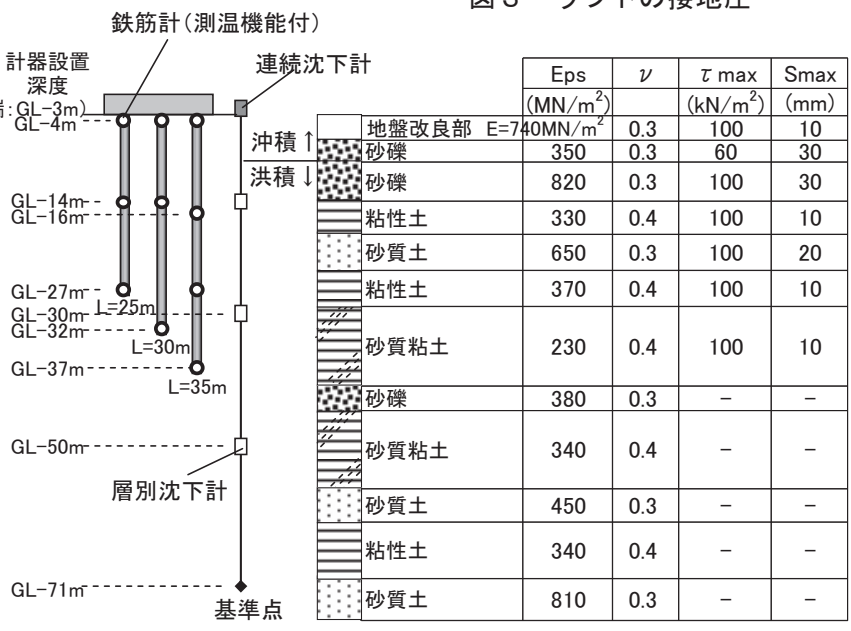

$\sigma z^{\prime}$ : 有効上載压, Pc: 压密降伏応力, L: 杭長, Eps: PS検層から求めた变形係数、 $\mathrm{E}:$ 変形係数、 $\nu$ :ポアソン比、 $\tau$ max: 極限周面摩擦力度、Smax: $\tau \max$ a時の杭の変位

図 4 地層構成、地盤定数、計器の埋設深度

係数はPS 検層から求めた微小ひずみレベルにおける変形係数 $E_{0}$ と し，地盤のひずみ依存性は $G / G_{0} \sim \gamma$ 関係 ${ }^{2)}$ （図 6）を用いた。地 盤改良部は弾性ソリッド要素で, 変形係数は改良土の一軸圧縮強度 $q_{u}$ と $E_{50}$ (一軸圧縮試験から求まる変形係数）の関係式から設定 した ${ }^{3)}$ 。改良土の $q_{u}$ は, 設計用の $q_{u}$ から推定した現場コア強度と した。ラフトと杭は弾性ソリッド要素, 杭周面摩擦はバイリニア型 のインターフェース要素でモデル化した。ラフトと地盤の間にはバ ネ要素を設け，地震時の解析でスラブの浮上がりも考慮できるよう 
にした。

予測解析で得た即時沈下量分布図を図 7 , 増加地中応力コンター を図 8 に示寸。即時沈下量が最大 $14 \mathrm{~mm}$, 最大変形角が $1 / 1000$ と設 計上のクライテリアを満足した。

当初, 全ての杭の長さを一定としたパイルド・ラフト基礎に関し て概略検討を実施し，変形角が許容範囲内となる計算結果を得てい た ${ }^{4)}$ 。しかし, 地震時の変動軸力に対する杭の負担軸力は隅角部が 最大で, 耐震設計上, 必要とされる杭長は, 図 2 のように, 隅角部 $35 \mathrm{~m}$, 辺部 $30 \mathrm{~m}$, 中央部 $25 \mathrm{~m}$ であった。杭長が全て一定の杭基礎では, 沈下量は建物中央部，辺部，隅角部の順に小さくなる傾向を示す。 したがって, 隅角部, 辺部の杭長が長いと, 外周部の沈下量が小さ くなりすぎて, 変形角が許容值を超えることが懸念された。しかし， 本建物の荷重は内部より外周部で大きく, ラフトと基礎梁の剛性も かなり剛であることから，接地圧も外周部ほど大きくなる分布形状 を示す (図 8)。このような接地圧分布は建物の不同沈下の低減に有 利であり，予測解析でもほぼフラットな沈下量分布が得られた。

また, 圧密沈下量についても, FEM で得た増加地中応力によると, 深さ $15 \sim 50 \mathrm{~m}$ の各粘性土層において, 建物建設後の地中応力は, 過 圧密比が 1.5 程度の過圧密領域に留まる。したがって, 有害な圧密 沈下が生じることはなく,図 2 の杭配置で差し支えないと判断した。

この杭配置では, 長期荷重時におけるラフトの荷重分担率は $66 \%$, 杭の安全率は負担荷重に対して $3.0 \sim 3.2$ となった。

(2) 予測解析と実測との比較

本建物では，ラフトの施工開始から竣工時までの期間において,
沈下量を連続沈下計と層別沈下計, 杭軸力を測温機能付き鉄筋計に よって現場計測を行った。沈下量は最も沈下量が大きいと思われる 建物中央部において, また, 杭軸力は 3 種類の杭長毎に 1 本ずつ, 合計 3 本計測した（図 2)。

ラフト直下における沈下量の経時変化, および沈下量の深度分布 をそれぞれ図 9，10 に示した。いずれについても予測值と実測值は よく対応している。本建物は地下階のない順打ち施工で, 建物の増 加荷重は躯体完了までほぼ等間隔であり, 沈下量の実測值もこれに 対応した経時変化を示している。躯体工事完了後に若干の荷重増と クリープによると考えられる約 $1.5 \mathrm{~mm}$ の沈下が生じているものの, 竣工時までにほぼ収束しており, 建物に有害な沈下が生じていない ことを確認できた。

竣工時における軸力深度分布を図 11 に示した。予測值と実測值の いずれについても, 地表面近くで杭周面摩擦力が発揮されにくい傾 向にある。これは, ラフト下の地盤が荷重を負担することによって 沈下し, ラフト直下の地盤と杭が共下がりするので, 杭と地盤の相 対変位が生じにくいためと考えられる。図 8 の増加地中応力コンタ 一においても, ラフト下の増加地中応力の高い領域では杭と地盤が 一体となって挙動する状況がうかがえる。また, 杭先端軸力の実測 值が予測值に比べて小さくなった原因として, 予測解析で仮定した 極限周面摩擦力度 $\tau_{\text {max }}$ が実測より小さく, また, 仮定した $\tau_{\text {max }}$ 到 達時の杭の変位が実測より大きかったことなどが推察される。なお, 場所打ち杭先端部のスライム処理など, 杭の施工管理に問題は生じ なかった。また，地中部の鉄筋計温度はほぼ一定であるが，杭頭部

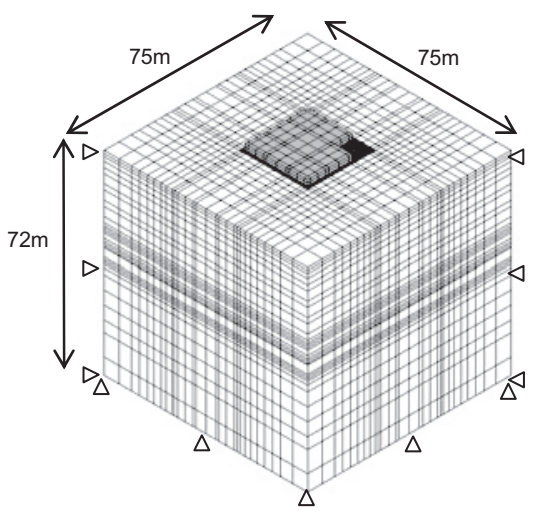

図 5 F E M解析モデル
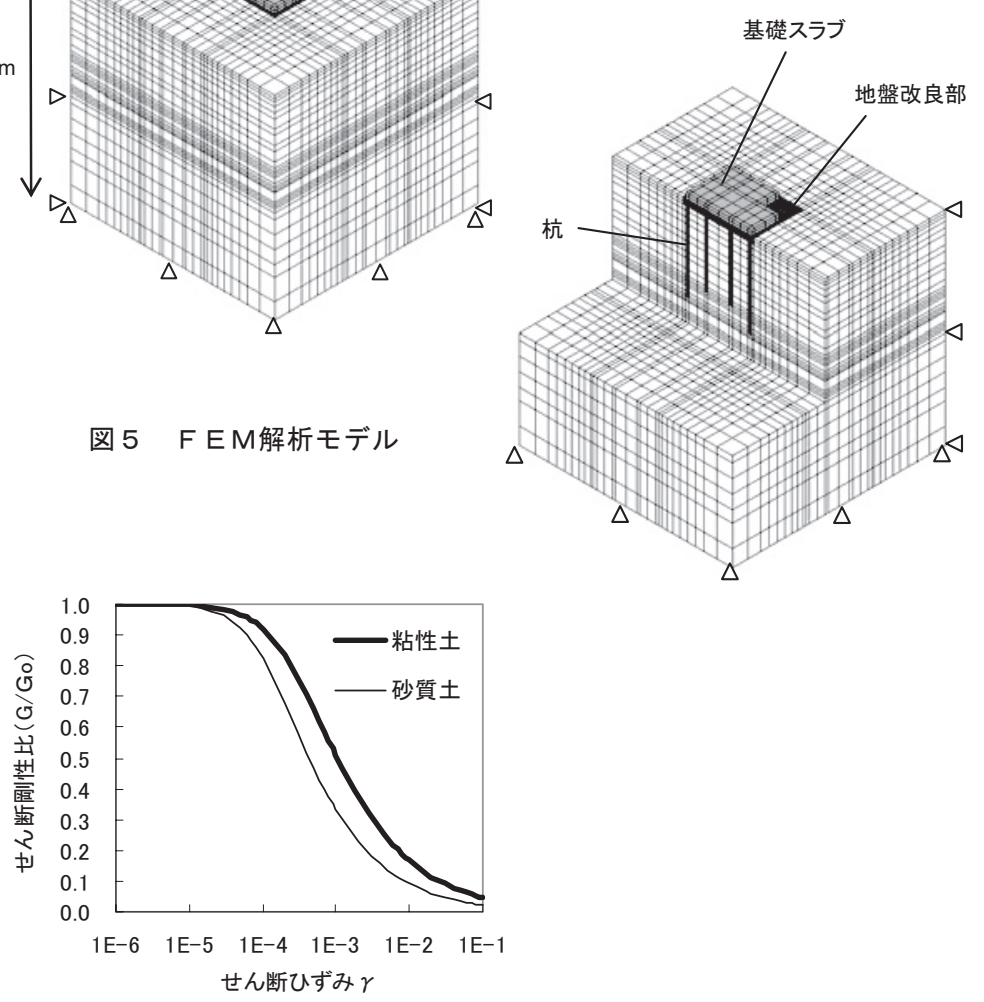

図 6 地盤のひずみ依存性 ${ }^{2)}$

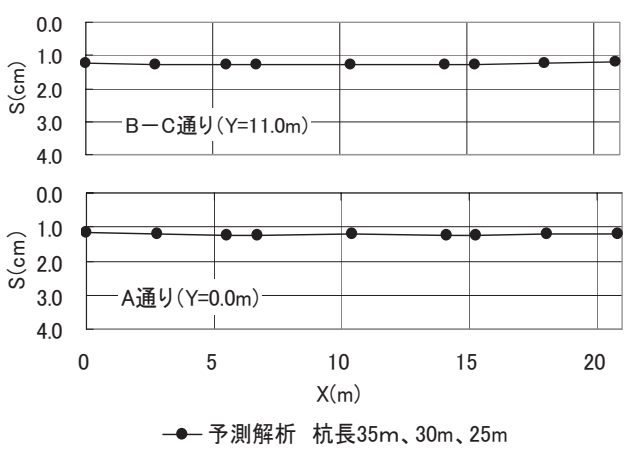

図 7 ラフト上の沈下分布図（長期荷重時）

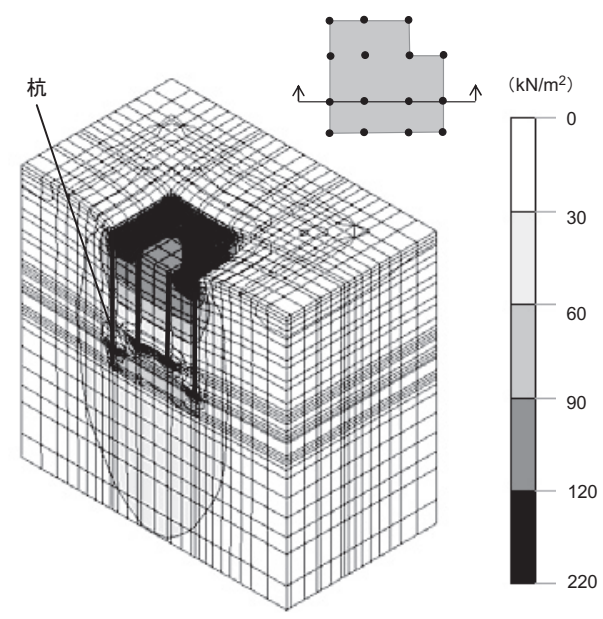

図 8 増加地中応カコンター（長期荷重時） 


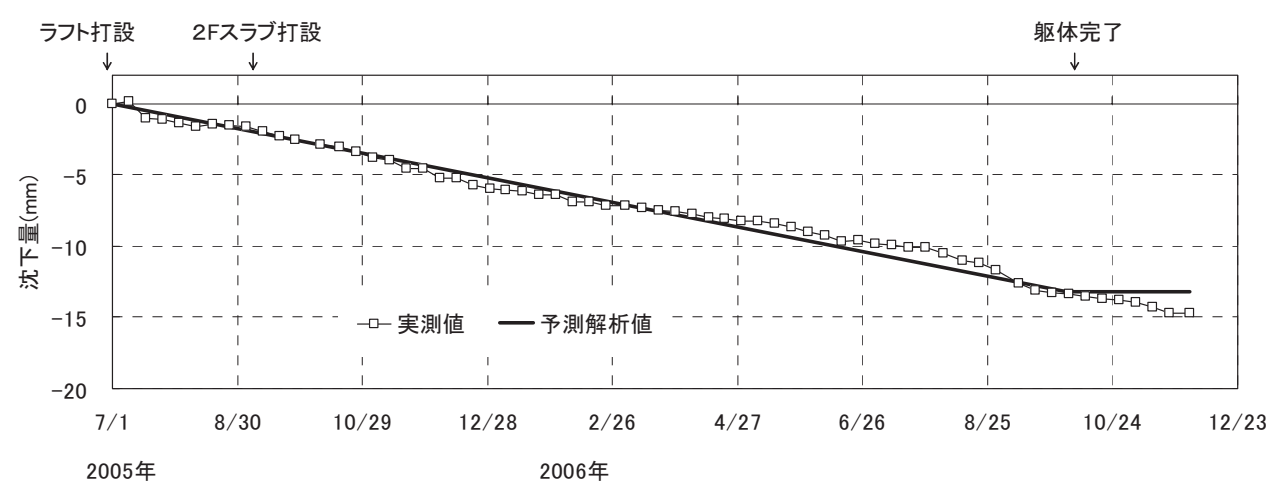

図 9 基礎スラブ直下における沈下量経時グラフ（長期荷重時）

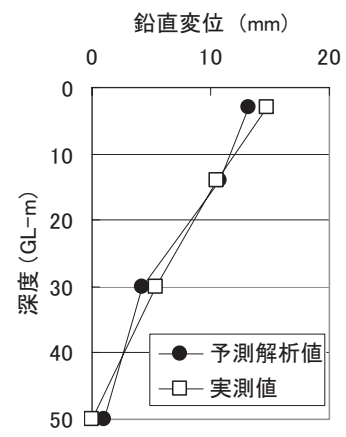

図 10 沈下量の深度分布図 （長期荷重時）
では外気温の寒暖の影響を受けており，竣工時の鉄筋計温度の実測 值はラフト打設時よりも $13^{\circ} \mathrm{C}$ 低下した。そこで計測期間中の荷重一 定期間の実測值を吟味すると $1{ }^{\circ} \mathrm{C} の$ 低下で $4 \mu$ 程度の引張り歪みを 生じており，軸力評価において無視できない程度であったので，こ の $1{ }^{\circ} \mathrm{C}$ 当たりの歪みの变化量を用いて杭頭のみ温度補正を行った。

実測值に基づく建物全体における地盤と杭の荷重分担率は，各杭 の予測杭頭軸力から次の手順で推定した。(1)同一の杭長であっても, 杭の位置に応じて予測杭頭軸力が異なるため, 計測の対象と寸る杭 を基準として各杭の予測杭頭軸力比 $\alpha_{i}$ を設定する。(2)各杭の推定実 測杭頭軸力 $N_{i}$ は, 同じ杭長の実測杭頭軸力 $N_{k}$ に各杭の $\alpha_{i}$ を乗じ た值とする $\left(N_{i}=\alpha_{i} \times N_{k}\right)$ 。(3)杭の全分担荷重 $P_{p}$ は, (2)で求めた $N_{i}$ の和とする。(4)地盤の全分担荷重は, 設計用の建物全体荷重か ら $P_{p}$ を差し引いた值とする。その結果, 建物全体における長期荷 重時の荷重分担率は, 予測解析のラフト : 杭=66\%: $36 \%$ に対して 60\%：40\%であり，設計時に考慮した余裕度の範囲であることを確 認した。

\section{4. 地震時の検討}

地震時の転倒モーメントによるラフトの浮上りを考慮に入れて, 水平力に対するパイルド・ラフト基礎の検討を行った。なお，本報 告で採用した FEM モデルの要素分割と地盤定数の設定法は，建物の 実測沈下挙動をほぼ良好にシミュレートできることが，過去の多く の実積から明らかになっている。しかし, 同一の FEM モデルで地震 時の鉛直および水平荷重を同時に受ける基礎の複雑な挙動をシミュ レート可能であるとの検証は行っていない。したがって,ここでは 実務設計上，地震時の鉛直および水平荷重によって基礎に発生する 応力を，それぞれ別途求めて部材の断面設計を行う方針とした。

\section{1 地震時鉛直荷重に対する検討}

\section{(1) 検討手順}

(1)ラフト, 杭, 地盤系の FEM モデルに地震時の柱軸力を作用させ,

ラフトの浮上りゾーンと接地ゾーンを把握する。

(2)基礎スラブの最大接地圧, 杭が負担する押込み荷重, 引抜き荷 重等を求める。

(3)杭の押込み荷重, 引抜き荷重に対して, 鉛直支持力, 引抜き抵 抗力, 杭体断面の検討を行う。

(4)ラフトの負担接地圧に対してラフトの断面設計を行う。

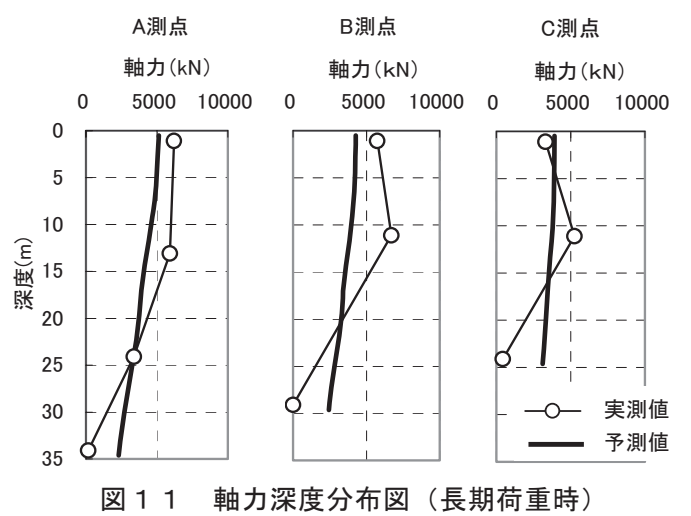

（2）検討方法および検討結果

（1）(1)の解析には 3 . 節と同様に, 汎用非線形 FEM ソフト ABAQUS を使用した。ラフトと地盤はばね要素で連結し, 図 12 に示寸非線形 ばね特性を与えることによりラフトの浮上りを考慮した。なお，地 盤定数および基礎スラブ, 杭の諸定数は, 長期の沈下解析に使用し た值と同一とした。

検討は, 設計用地震荷重時, 保有耐力時の 2 ステップについて行 った。検討結果によると, 設計用地震荷重時においてはラフトに浮 上りは生じない。保有耐力時においては, ラフトに浮上りが生じ, 隅角部の杭およびそれに隣接する辺部の杭が引抜き力を受ける。浮 上りは, 載荷方向に応じてラフト全平面の約 $18 ３ 2 \%$ 範囲に生じ た。浮上り量, 沈下量は 45 度方向加力時に最大となり, 最大浮上り 量は約 $1.1 \mathrm{~cm}$, 最大沈下量は約 $4.0 \mathrm{~cm}$ であった。代表例として,X 方向および，45 度方向載荷時の増加地中応力コンターを図 13,14 に示した。各図において, 図中右上の平面図の白色部分が浮上りの 範囲を示している。ラフト直下と杭周面および杭先端から増加地中 応力の応力球根が形成され, 特に, 押込み側のラフト直下の地盤と 杭先端に増加地中応力の大きい部分が生じていることがわかる。こ のとき，杭の引抜き荷重および押込み荷重は，それぞれ地盤による 杭の極限引抜き抵抗力, 極限支持力を下回ることを確認した。また, ラフトの接地部分について地震時の鉛直荷重の分担率を求めると, 浮上りのない設計用地震荷重時で $64 \sim 67 \%$ と長期荷重時と同程度, 浮上りが生じる保有耐力時でも $64 \sim 70 \%$ と大きな変化はなかった。

\section{2 地震時水平荷重に対する検討}

(1) 検討手順

(1)基礎に地震時の水平力が作用するときのラフトの接地ゾーンを 
考慮に入れたラフトと杭との荷重分担を求める。

(2)ラフトの負担水平力がラフトの接地ゾーンの最大摩擦抵抗力を 上回らないことを確認する。

(3)杭の負担水平力に対して杭体の断面設計を行う。

パイルド・ラフト基礎の水平抵抗の検討に際しては, 厳密には地 盤を介した杭とラフトの相互作用を考慮する必要がある。しかし， ここでは略算法として, 負担荷重に応じたラフトの変位に伴う地盤 変位の影響と，地震時におけるラフト周辺の地盤変位による影響を 応答変位法により評価することにした。この方法は，パイルド・ラ フト基礎の模型水平載荷試験結果をほぼ良好にシミュレートできる ことを確認している5 ${ }^{5}$ 。

（2）ラフトの負担水平力〜変位の関係，およびラフトの変位に伴 う地盤変位の深度分布の算定

ラフト直下の地盤変位は, 図 15 に示寸コーンモデル ${ }^{6)}$ を用いて, ラフトの荷重〜変位関係（図 17 中の曲線 (1) ) および各荷重レベル での地中の地盤変位分布 $\delta(z)$ を(1) 式を用いて算定した。多層系地 盤においては, 各層の変位を重站合わせて全体系の地盤変位分布と する。その際，地盤の非線形性を考慮する。また，ラフトに浮上り が生じる場合，ラフトの接地ゾーンを等価な円形基礎に置換して評 価した。

$$
\begin{aligned}
& \delta_{0}=\frac{Q_{r}}{K_{h b}}, \quad \delta(z)=\delta_{0} \frac{Z_{h 0}}{Z} \\
& K_{h b}=\pi G \frac{r_{h 0}^{2}}{Z_{h 0}}, \quad Z_{h 0}=\pi r_{h 0} \frac{2-v}{8}
\end{aligned}
$$

ここに, $Q_{r}$ : ラフトの負担水平力, $v$ : 底面直下のポアソン比, $G$ : 地盤のせん断剛性, $Z_{h 0}$ : コーン頂点からの距離, $r_{h 0}$ : 水平 地盤ば水算定用の等価基礎半径, $K_{h b}$ : 基礎の水平地盤ばね $\delta_{0}:$ ラフトの水平変位

\section{（３）地震時の地盤変位の算定}

地震時の地盤変位は，等価線形化手法である SHAKE を用いて算定 した。表 2 にPS 検層結果より求めた地盤定数を示した。工学的基盤 は GL-71.8m の砂質土層上面に設定し, 地盤の非線形性は, 図 6 に示 寸告示 1457 号で示された粘性土，砂質土の非線形特性を与えた。ま た，入力地震波として，平成 12 年建設省告示 1461 号第四号イに定 められた解放工学的基盤における加速度応答スペクトルに適合した 地震波を用い，入力地震動のレベルは極めて稀に発生する地震動レ ベルとした。図18に各杭の杭先端からの相対変位を示す。杭頭から $10 \mathrm{~m}$ 程度の梁度では，地盤変位はほぼ一定で大きな増幅はない。

（4）杭の負担水平力〜水平变位の関係

ラフトに水平力 $Q_{r}$ と地震時の地盤変位が同時に作用し, ラフト が $\delta_{0}$ 変位した場合の, 杭の負担水平力および応力と変位を, 応答変 位法を用いて算定した。すなわち図 16 に示すように，(2)，(3)で算 定した地盤变位を地盤ばねを介して杭に作用させるとともに, 杭頭 に水平力を作用させて, 杭頭変位がラフト変位 $\left(\delta_{0}\right)$ と等しくなる 杭頭水平力 $Q_{p}$ を求める。この手順を繰返し, 杭の負担水平力〜水 平変位の関係を求める (図 17 中の曲線 $(2)$ )。

なお，解析に用いた地盤ば拜は，砂質土は $N$ 值から，粘性土は一 軸圧縮試験結果から求めた変形係数 $E_{50}$ を用いて算定した。また,

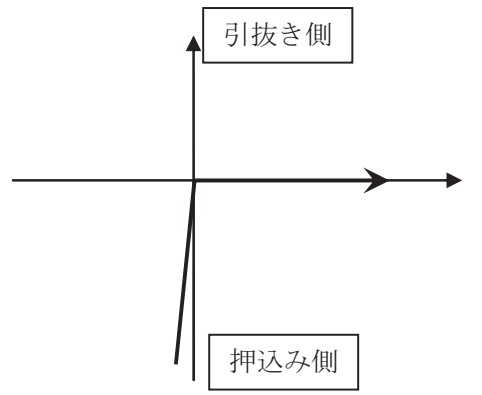

基礎スラブと地盤の連結ばね復元カモデル

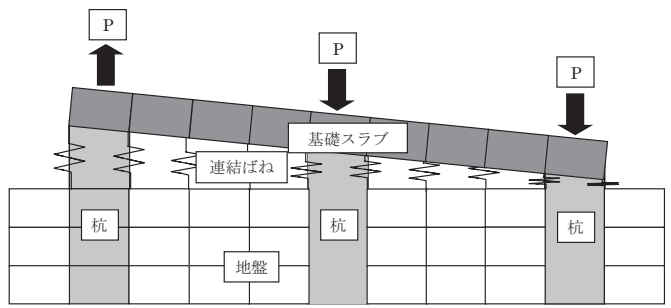

図 12 基礎スラブと地盤の連結ばね

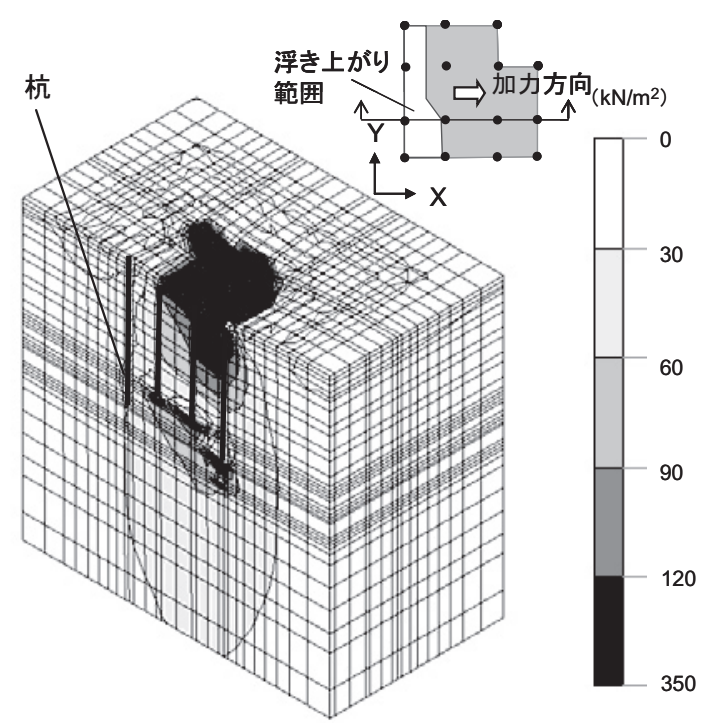

図 13 増加地中応力（X方向載荷時）

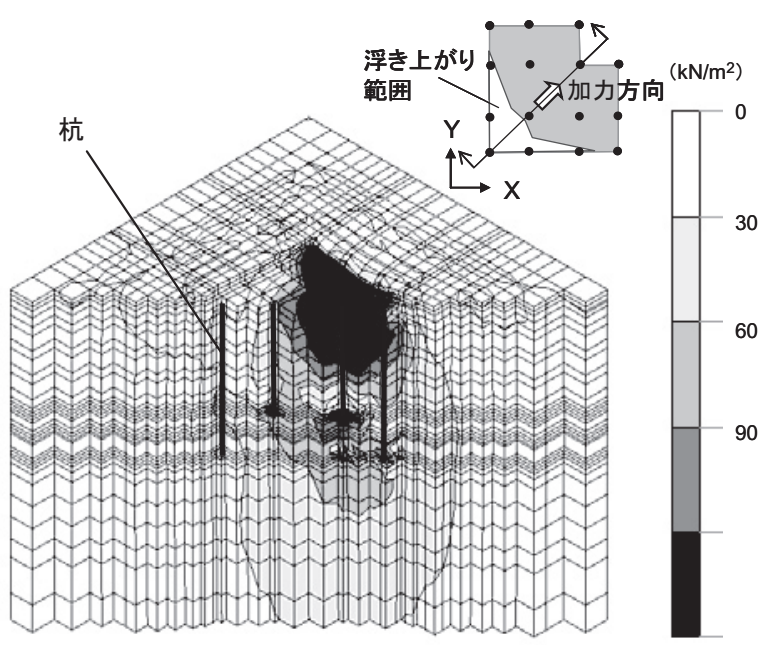

図 14 増加地中応力（45 度方向載荷時 $)$ 


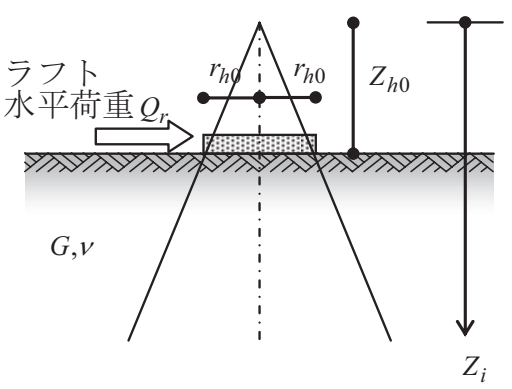

図 15 コーンモデル

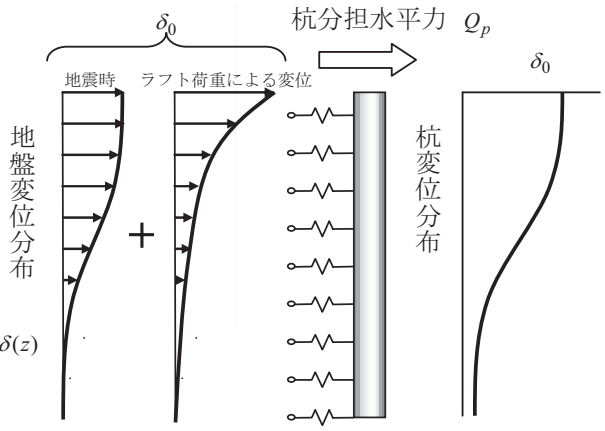

図 16 杭分担水平力の算定法

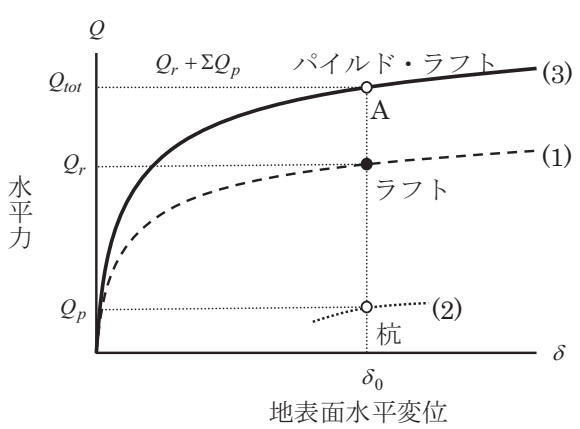

図 17 パイルド・ラフト基礎の水平抵抗
ラフトに作用させる水平力 $Q_{r}$ は, 設計用地震荷重時, 保有耐力時 の 1 階層せん断力に, 基礎重量にそれぞれ水平震度 $0.1,0.2$ を乗じ て算定した水平力の和とした。

（5）パイルド・ラフト基礎の荷重～水平変位の関係およびラフト と杭の荷重分担

想定寸る水平変位に対応するラフトの負担水平力 $Q_{r}$ と全杭の負 担水平力 $\Sigma Q_{p}$ とを足し合わせることによって, パイルド・ラフト基 礎に作用する全水平力 $Q_{t o t}$ を算定し, パイルド・ラフト基礎全体の 荷重〜水平変位の関係を求めた（図 17 中の曲線(3))。図 17 におい て,パイルド・ラフト基礎全体に作用する設計用水平荷重から杭とラ フトの荷重分担率を評価した（図 17 中の点 A)。

下記の 2 種類の組合わせについて, 杭の曲げモーメント分布を求 め,それらの比較を図 19 に示した。

(1) 杭頭水平力十ラフトの変位に伴う地盤変位

(2) 杭頭水平力 + ラトの変位に伴う地盤変位十地震時地盤変位 曲げモーメント分布はいずれも, 図 19 の太線で示す全水平力を杭 で負担させた場合の杭頭曲げモーメントの值で規準化している。こ の図から，この建物の基礎としてパイルド・ラフト基礎を採用寸る と, 杭基䃈と比較して杭頭の負担応力を 6 割程度に低減できること がわかる。また, 本検討条件では, 総じて地震時の地盤変位の影響 は小さい。

ラフトの水平変位は, 設計用地震荷重時, 保有耐力時でそれぞれ 約 $3 \mathrm{~mm}$, 約 $8 \mathrm{~mm}$ となった。水平変位が小さいのは, ラフト直下に $N$ 值が 20〜50 の締まった砂硆層が堆積しているためと考えられる。 また, ラフトの水平力の分担率は, 設計用地震荷重時, 保有耐力時 でそれぞれ，64\%，49\%となった。これは, 保有耐力時にはスラブ に浮上りが生じて接地面積が減少したため, ラフトの負担が低下し たものと考えられる。

\section{5. まとめ}

高層建物を支持する基礎として, 地震時軸力の大きさに応じて長 さの異なる摩擦杭を配置したパイルド・ラフト基礎を計画・立案し た。この基礎の沈下予測解析結果と実測結果は良好な対応を示した。 また，大地震時の上部構造の転倒モーメントによるラフトの浮上り ゾーンをFEM によって求め, この浮上りゾーンを考慮した基礎の静 的耐震設計の概要を示した。地震時に浮上りを生じるようなパイル ド・ラフト基礎の挙動については, 動的解析や遠心模型実験などに よる検討が望ましいと考えられるが，今後の課題としたい。

\begin{tabular}{|c|c|c|c|c|}
\hline $\begin{array}{c}\text { 深度 } \\
(\mathrm{m})\end{array}$ & 地質 & $\begin{array}{c}\text { 層厚 } \\
(\mathrm{m})\end{array}$ & $\begin{array}{c}\text { S波速度 } \\
\left(\mathrm{m} / \mathrm{s}^{2}\right)\end{array}$ & $\begin{array}{c}\text { 密度 } \\
\left(\mathrm{g} / \mathrm{cm}^{3}\right)\end{array}$ \\
\hline 0.0 & $\mathrm{Ag}$ & 5.0 & 390 & 2.00 \\
\hline 5.0 & $\mathrm{Ag}$ & 5.3 & 390 & 2.00 \\
\hline 10.3 & $\mathrm{Dg}$ & 4.4 & 530 & 2.00 \\
\hline 14.7 & $\overline{D c}$ & 5.0 & 260 & 1.59 \\
\hline 19.7 & $\overline{D s}$ & 4.1 & 350 & 1.80 \\
\hline 23.8 & Ds & 5.4 & 270 & 1.70 \\
\hline 29.2 & $\overline{D c}$ & 1.0 & 270 & 1.80 \\
\hline 30.2 & $\overline{\mathrm{Dc}}$ & 4.6 & 220 & 1.60 \\
\hline 34.8 & $\mathrm{Dg}$ & 2.9 & 360 & 2.00 \\
\hline 37.7 & $\mathrm{Dc}$ & 8.0 & 260 & 1.68 \\
\hline 45.7 & $\mathrm{Dc}$ & 7.8 & 260 & 1.70 \\
\hline 53.5 & $\mathrm{Dc}$ & 5.6 & 290 & 1.68 \\
\hline 59.1 & $\mathrm{Dg}$ & 3.2 & 290 & 1.80 \\
\hline 62.3 & $\overline{D c}$ & 9.5 & 260 & 1.68 \\
\hline 77.8 & $\overline{D s}$ & & 390 & 1.70 \\
\hline
\end{tabular}
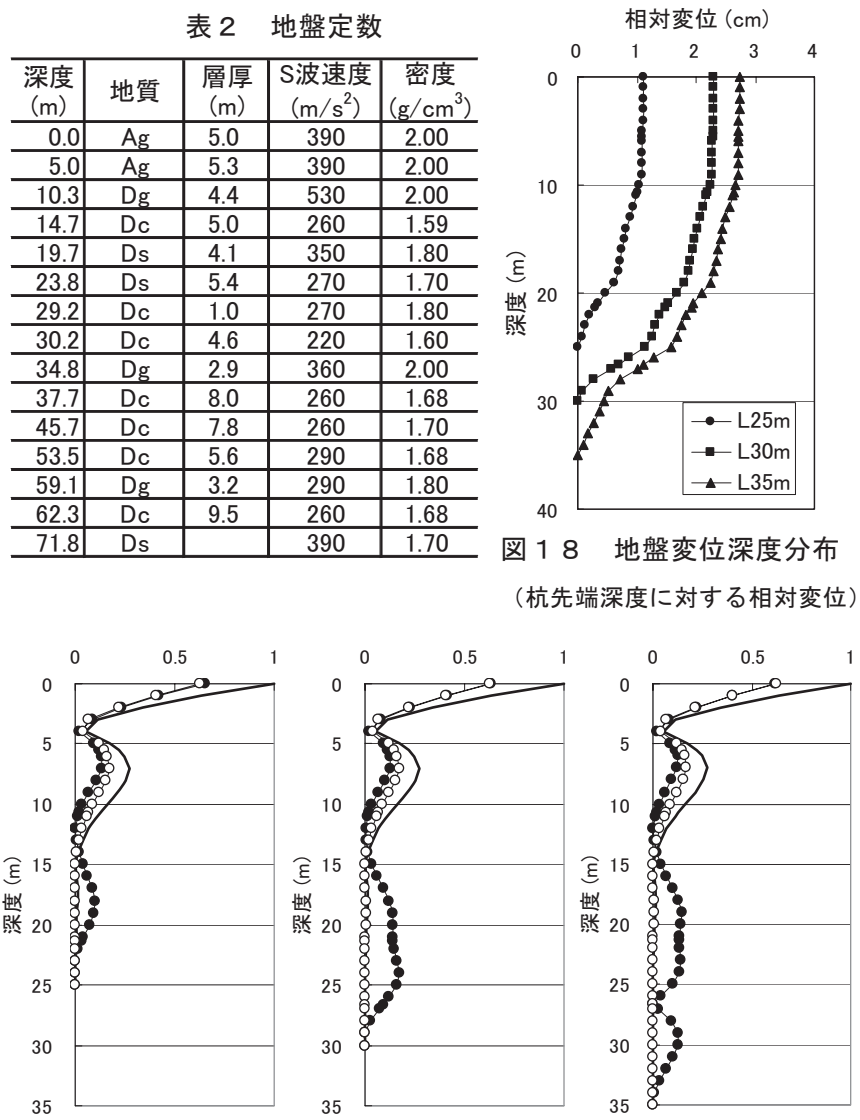

$\mathrm{O}:$ 杭頭水平カ十ラフト荷重よる地盤変位

○: 杭頭水平カ十ラフト荷重よる地盤変位十地震時地盤変位

一: 全水平力を杭で負担させた場合

図 19 曲げモーメント分布の比較

\section{参考文献}

1) 柴田, 山下, 濱田, 室屋: 逆打ちで構築したパイルド・ラフト基礎を採用 した超高層建物の沈下挙動, 日本建築学会大会学術講演梗概集 B-1, pp. 699 $\sim 670,2005.9$

2)平成 12 年建設省告示第 1457 号，別表第一

3) 日本建築センター編 : 改訂版建築物のための改良地盤の設計及び品質管理 指針第 1 版, 2002.11

4) 鈴木, 関, 茶谷, 佐俣, 田中：超高層建物を支持する杭長の異なるパイル ド・ラフト基䃈，基礎工，Vol. 33，No. 12，pp79〜81，2005.12

5) 石井, 関, 西山, 藤森: 大型せん断土槽実験によるパイルド・ラフト基礎 の地震時簡易評価（その 3 ）簡易設計法の検討, 日本建築学会大会学術講演 梗概集 B-1，pp. 491 492，2003.9

6) 国土交通省建築研究所編 : 改正建築基準法の構造関係規定の技術的背景, ぎょうせい 